\title{
24. ROCK MAGNETIC PROPERTIES, MAGNETIC MINERALOGY, AND PALEOMAGNETISM OF PERIDOTITES FROM SITE 895, HESS DEEP'
}

\author{
Paul R. Kelso, ${ }^{2}$ Carl Richter, ${ }^{3}$ and Janet E. Pariso ${ }^{4}$
}

\begin{abstract}
Serpentinized oceanic peridotites collected during Ocean Drilling Program Leg 147 at Site 895 in the Hess Deep were studied magnetically to further our understanding of the magnetization of the oceanic lithosphere. The majority of the samples are dunites and harzburgites, with varying degrees of serpentinization. Rock magnetic studies suggest that the dominant magnetic mineral is relatively pure pseudo-single-domain magnetite. Optical observations reveal that the magnetite has a secondary origin related to the serpentinization process. The dunites and the harzburgites have median natural remanent magnetization values of 3.2 and $1.2 \mathrm{~A} / \mathrm{m}$ and magnetic susceptibility values of 0.053 and 0.023 (SI volume units), respectively. The NRM is the dominant component of magnetization and has a magnitude similar to values observed for oceanic basalts of Layer $2 \mathrm{a}$. Similarly serpentinized peridotites residing within the oceanic lithosphere are likely contributors to magnetic anomalies. Thermal and alternating-field demagnetizations usually yield a stable remanent magnetization direction that often has an inclination much greater than expected for the time-averaged geomagnetic field $\left(>5^{\circ}\right)$ at Site 895 . This disparity suggests that the samples acquired their magnetization and were subsequently reoriented. Hole $895 \mathrm{E}$ samples have relatively coherent inclinations $\left(30^{\circ}\right)$ that become shallower in the bottom $30 \mathrm{~m}$ of the hole. Inclinations in Hole $895 \mathrm{D}$ vary from $+60^{\circ}$ to $-60^{\circ}$, with no systematic trends evident with depth in the hole, suggesting differential vertical rotation of blocks on a scale of a few meters. Experimental evidence suggests that room-temperature magnetic viscosity does not significantly effect the magnetization intensity or direction of these samples.
\end{abstract}

\section{INTRODUCTION}

Ocean Drilling Program (ODP) Leg 147 (Gillis, Mével, Allan, et al., 1993) collected hard-rock samples from the intrarift ridge of Hess Deep in the central east Pacific Ocean (Fig. 1). The samples recovered at Site 894 were mostly gabbroic rocks from the lower oceanic crust, whereas samples from Site 895 were dominated by serpentinized peridotites likely from the uppermost mantle (Gillis, Mével, Allan, et al., 1993). The magnetic properties of the samples of Site 894 are discussed in a companion paper by Pariso et al. (this volume). This paper concentrates on the magnetic properties of samples from Site 895 , particularly from Holes $895 \mathrm{D}$ and $895 \mathrm{E}$, which had the greatest recovery and deepest seafloor penetration $(93.7 \mathrm{~m}$ and 87.6 $\mathrm{m}$, respectively). These cores contained peridotites from the oceanic lithosphere, with harzburgites dominant in Hole 895D and dunites in Hole $895 \mathrm{E}$. This study more than doubles the number of serpentinized peridotite samples analyzed magnetically from ocean drilling studies (Dunlop and Prévot, 1982; Smith and Banerjee, 1985; Bina et al., 1990; Bina and Henry, 1990; Hamano et al., 1990). Previous studies involved sites where peridotite samples were found at "anomalously" shallow depths in the oceanic lithosphere, for example, in fracture zones and complicated tectonic regions. Thus, the process of formation and subsequent alteration may not be representative of "typical" oceanic crust, and the resulting magnetic properties from these anomalous sites may not be representative of the oceanic crust

'Mével, C., Gillis, K.M., Allan, J.F., and Meyer, P.S. (Eds.), 1996. Proc, ODP, Sci. Results, 147: College Station, TX (Ocean Drilling Program).

${ }^{2}$ Lake Superior State University, Sault Ste. Marie, MI 49783, U.S.A. pkelso@lakers.lssu.edu

${ }^{3}$ Ocean Drilling Program, 1000 Discovery Drive, Texas A\&M University Research Park, College Station, TX 77845, U.S.A. carl_richter@odp.tamu.edu

${ }^{4}$ School of Oceanography, University of Washington, Seattle, WA 98195 , U.S.A. pariso@ocean.washington.edu

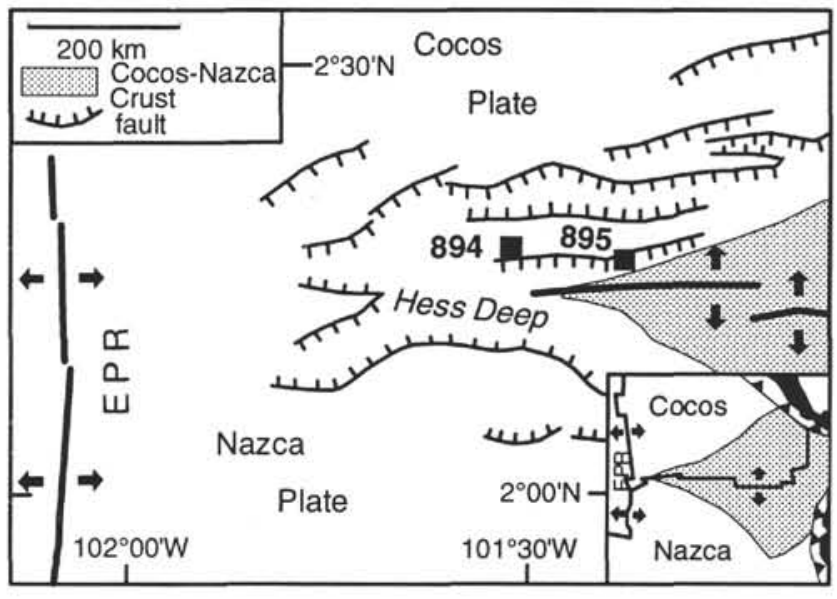

Figure 1. Location map of Sites 894 and 895 and the generalized tectonic setting of Hess Deep near the junction of the East Pacific Rise (EPR) and the Galapagos spreading center (after Lonsdale, 1988).

in general. The Site 895 peridotites formed at a typical fast-spreading center, the East Pacific Rise, and are now exposed at Hess Deep, at the tip of the westward-propagating Cocos-Nazca Ridge. A review of the geologic setting and tectonic history at Site 895 can be found in articles by Lonsdale (1988), Francheteau et al. (1990), Gillis, Mével, Allan, et al. (1993), MacLeod et al. (this volume), and Mével and Gillis (this volume).

Samples from Hole $895 \mathrm{E}$ were more altered than those of Hole $895 \mathrm{D}$, with the former often containing $>90 \%$ secondary minerals. All peridotite samples were highly serpentinized, typically $70 \%$ or more. For a detailed analysis of the igneous and metamorphic petrology of Site 895, see Arai and Matsukage (this volume), Früh-Green et al. (this volume), and Mével and Stamoudi (this volume). 
A continuing debate among geophysicists is the relative contributions of the different oceanic layers to marine magnetic anomalies (e.g., Toft and Arkani-Hamed, 1992, 1993). A major limitation to our understanding of marine magnetic anomalies has been our lack of knowledge of the magnetic properties of units below the extrusive basalts of Layer 2a, largely due to the scarcity of samples from the deeper units. The peridotites of Site 895 provide a unique new data set of the magnetic properties for specimens from near the crust/mantle boundary.

\section{EXPERIMENTAL PROCEDURES}

Measurements of saturation magnetization $\left(J_{s}\right)$ vs. temperature (T) were made from room temperature $\left(22^{\circ} \mathrm{C}\right)$ to $700^{\circ} \mathrm{C}$ on a vibrating sample magnetometer equipped with a furnace, at the Institute for Rock Magnetism (IRM) at the University of Minnesota. The temperature was monitored by a thermocouple that was in contact with the sample $(\approx 100 \mathrm{mg})$. The sample was wrapped in silver foil to facilitate a homogeneous temperature distribution. The applied magnetic field was $500 \mathrm{mT}$. The sample chamber was evacuated and then backfilled with helium several times before each $J_{s}$ vs. $T$ run to purge the system of oxygen, to reduce the chance of oxidation, and to facilitate heat transfer. Curie temperatures $\left(T_{c}\right)$ were calculated graphically from these curves. Hysteresis loops confirm that $500 \mathrm{mT}$ is sufficient to magnetically saturate the samples. Hysteresis loops were generated at the IRM for a variety of samples whose masses ranged from 0.01 to $10 \mathrm{~g}$. A Quantum Design superconducting susceptometer was used to measure the temperature dependence of saturation remanence as it was heated in zero magnetic field. Samples $(\approx 100 \mathrm{mg})$ were saturated by a $500-\mathrm{mT}$ field at $15 \mathrm{~K}$ (SIRM[15K]). Measurements were taken every 5 to $10 \mathrm{~K}$ as the sample was heated from $15 \mathrm{~K}$ to $300 \mathrm{~K}$ in zero magnetic field (i.e., less than a few millitesla).

The samples used for directional analysis were cylindrical specimens drilled from the working half of the core. The minicores were approximately $2.5 \mathrm{~cm}$ in diameter and $2.2 \mathrm{~cm}$ in length. NRM measurements were made with a $2 \mathrm{G}$ magnetometer aboard the JOIDES Resolution and at the IRM, and with a CTF cryogenic magnetometer at Texas A\&M University. The NRM was stepwise demagnetized with either alternating field (AF, maximum field $100 \mathrm{mT}$ ) or thermally in zero field (maximum temperature $600^{\circ} \mathrm{C}$ ). For long minicores, the 2.5 - by $2.2-\mathrm{cm}$ trimmed minicore was AF demagnetized and the remaining end piece was thermally demagnetized. Thermal demagnetization was conducted in a Schonstedt thermal demagnetizer in which the sample was held at temperature for 30 to 45 min depending on sample size. AF demagnetization was accomplished using a single-axis Schonstedt AF demagnetizer.

\section{Magnetic Mineralogy and Rock Magnetic Properties}

An understanding of marine magnetic anomalies and the magnetic properties of the oceanic lithosphere requires knowledge of the concentration and composition of the dominant magnetic minerals in representative rocks. The mineralogy of the phases that contribute to the magnetization of samples from Site 895 was examined through magnetic studies, including measurements of saturation magnetization vs. $T$, saturation remanent magnetization vs. $T$, susceptibility vs. $T$, hysteresis loops, and AF and thermal demagnetization of the NRM.

The measured peridotite samples have Curie temperatures in the narrow temperature range between $560^{\circ}$ and $585^{\circ} \mathrm{C}$, with a median value of $578^{\circ} \mathrm{C}$ (Fig. 2; Table 1). The curves are essentially reversible, implying that little chemical change occurred during the heating process. This suggests that the dominant magnetic mineral is nearly pure magnetite $\left(T_{c}=585^{\circ} \mathrm{C}\right)$. Minor substitution of other elements (e.g., $\mathrm{Ti}, \mathrm{Al}, \mathrm{Mg}$ ) decreases the Curie temperature of magnetite. There is no evidence of the phase transition that is commonly ob-

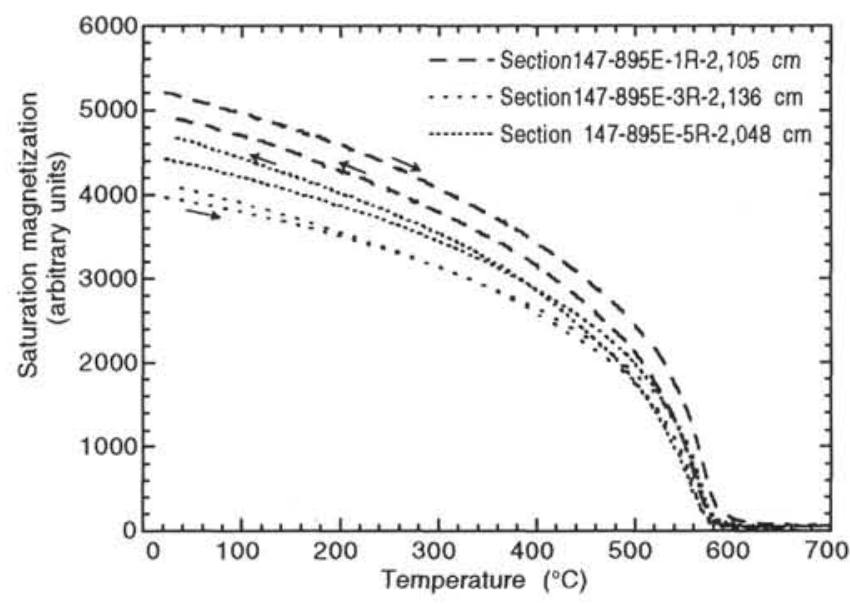

Figure 2. Representative saturation magnetization vs. temperature curves that were used for Curie temperature determinations.

served for oxidized titanomagnetites characteristic of oceanic basalts (e.g., Prévot et al., 1981; Beske-Diehl, 1990).

Heating the SIRM $[15 \mathrm{~K}]$ of a few typical samples in zero magnetic field (Fig. 3) reveals a large decrease in magnetization between 100 and $120 \mathrm{~K}$ due to a lattice transition (Verwey) in magnetite. There is no evidence of the hematite transition that occurs at around $260 \mathrm{~K}$. The change in slope of the curve between 30 and $40 \mathrm{~K}$ has several potential causes: (1) it could be due to the thermal demagnetization of extremely fine-grained magnetites, (2) a lattice transition in pyrrhotite that occurs at $35 \mathrm{~K}$, (3) the magnetic ordering of an ilmenite phase, or possibly (4) a magnetic ordering transition in an iron silicate phase. If superparamagnetic (SP) magnetite was abundant there would be a dramatic decrease in the magnetization at low temperature $(15-80 \mathrm{~K})$ and this may continue even at higher temperature (150$250 \mathrm{~K}$ ), but no such decrease was observed. Thus, it is concluded that samples do not contain a significant volume of magnetite that is SP at room temperature.

During thermal demagnetization the natural remanent magnetization decreases to zero at between $550^{\circ}$ and $600^{\circ} \mathrm{C}$ (Fig. 4). There are no other changes in slope of the demagnetization curve, which suggests that no other minerals, such as titanomagnetite or pyrrhotite, contribute significantly to the NRM.

Hysteresis loops were analyzed to determine the bulk magnetic coercivity, magnetic grain size, and concentration of magnetic mineral. The values of saturation magnetization $\left(J_{s}\right.$, extrapolated to zero field), saturation remanent magnetization $\left(J_{r s}\right)$, coercivity $\left(H_{c}\right)$, and coercivity of remanence $\left(H_{c r}\right)$ are recorded in Table 1 . A Day et al. (1977) plot of the hysteresis parameters (Fig. 5A) shows that the peridotites generally plot in the lower portion of the pseudo-single domain (PSD) region whereas the gabbronorites of Site 894 plot in the PSD-multidomain (MD) boundary region (Pariso et al., this volume). The harzburgites have on average higher $J_{r s} / J_{s}$ and lower $H_{c} / H_{c}$ ratios than the dunites (Fig. 5B). This suggests that on average the effective magnetic grain size of the harzburgites is slightly less than that of the dunites.

These magnetic measurements lead to the conclusion that PSD magnetite is the dominant magnetic mineral in the serpentinized dunite and harzburgite samples of Site 895. This is consistent with previous studies of serpentinized oceanic peridotites (e.g., Dunlop and Prévot, 1982; Krammer, 1990) and theoretical arguments (Frost, 1985, 1991; Toft et al., 1990). Observations made by reflected light microscopy show that the opaque minerals mainly occur within the serpentinized groundmass and along altered fractures within the less altered grains, particularly due to the serpentinization of olivine (Gillis, Mével, Allan, et al., 1993). This suggests that the opaque miner- 
Table 1. Summary of the magnetic properties of samples from Site 895

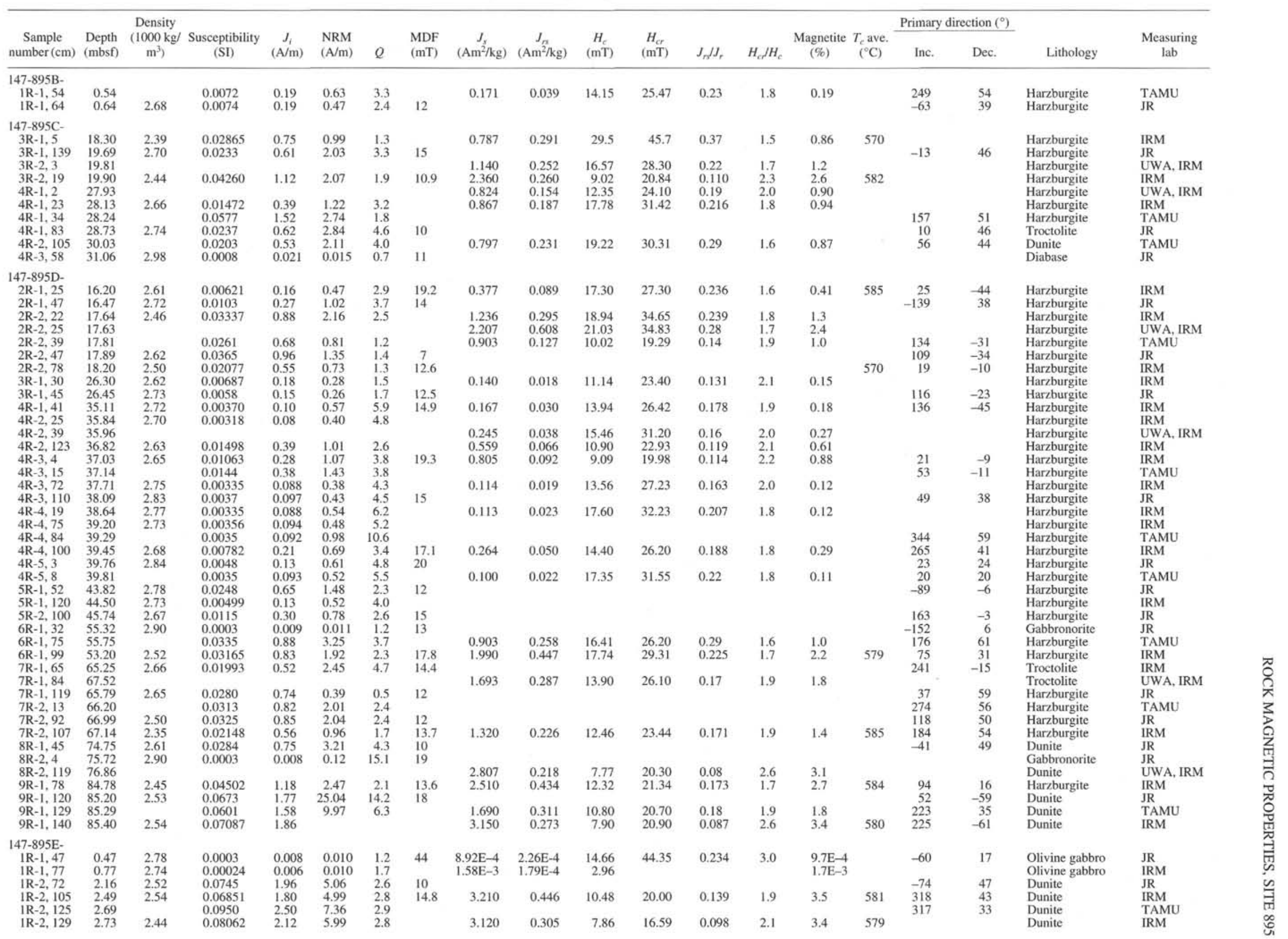


Table 1 (continued).

\begin{tabular}{|c|c|c|c|c|c|c|c|c|c|c|c|c|c|c|c|c|c|c|c|}
\hline \multirow[b]{2}{*}{$\begin{array}{c}\text { Sample } \\
\text { number }(\mathrm{cm})\end{array}$} & \multirow[b]{2}{*}{$\begin{array}{l}\text { Depth } \\
\text { (mbsf) }\end{array}$} & \multirow{2}{*}{$\begin{array}{c}\text { Density } \\
(1000 \mathrm{~kg} / \\
\left.\mathrm{m}^{3}\right)\end{array}$} & \multirow[b]{2}{*}{$\begin{array}{l}\text { Susceptibility } \\
\text { (SI) }\end{array}$} & \multirow[b]{2}{*}{$\underset{(\mathrm{A} / \mathrm{m})}{J_{i}}$} & \multirow[b]{2}{*}{$\begin{array}{l}\mathrm{NRM} \\
(\mathrm{A} / \mathrm{m})\end{array}$} & \multirow[b]{2}{*}{$Q$} & & & & & & & & & & Primary & ction $\left({ }^{\circ}\right)$ & & \\
\hline & & & & & & & $\begin{array}{l}\text { MDF } \\
(\mathrm{mT})\end{array}$ & $\begin{array}{c}J_{S} \\
\left(\mathrm{Am}^{2} / \mathrm{kg}\right)\end{array}$ & $\begin{array}{c}J_{r g} \\
\left(\mathrm{Am}^{2} / \mathrm{kg}\right)\end{array}$ & $\begin{array}{c}H_{c} \\
(\mathrm{mT})\end{array}$ & $\begin{array}{c}H_{c r} \\
(\mathrm{mT})\end{array}$ & $J_{r s} / J_{r}$ & $H_{c r} / H_{c}$ & $\begin{array}{c}\text { Magnetite } \\
(\%)\end{array}$ & $\begin{array}{c}T_{\mathrm{c}} \text { ave. } \\
\left({ }^{\circ} \mathrm{C}\right)\end{array}$ & Inc. & Dec. & Lithology & $\begin{array}{l}\text { Measuring } \\
\text { lab }\end{array}$ \\
\hline IR-3, 24 & 3.10 & & 0.0599 & 1.57 & 3.82 & 2.4 & & 1.840 & 0.314 & 12.15 & 22.36 & 0.17 & 1.8 & 2.0 & & 317 & 31 & Dunite & TAMU \\
\hline IR- $-3,49$ & 3.35 & 2.55 & 0.1135 & 2.98 & 5.34 & 1.8 & 10 & 3.94 & 0.56 & 10.17 & 20.44 & 0.142 & 2.0 & 4.3 & & 151 & 38 & Harzburgite & JR \\
\hline IR-3, 55 & 3.40 & & $\begin{array}{l}0.0802 \\
0.07478\end{array}$ & 2.11 & $\begin{array}{l}3.24 \\
3.45\end{array}$ & $\begin{array}{l}1.5 \\
1.8\end{array}$ & 8.8 & & & 1037 & 1000 & & & & & 64.1 & 35 & Harzburgite & UWA, IRM \\
\hline $\begin{array}{l}\text { IR-3, } 86 \\
\text { IR-3,95 }\end{array}$ & $\begin{array}{l}3.72 \\
3.79\end{array}$ & 2.53 & $\begin{array}{l}0.07478 \\
0.1170\end{array}$ & $\begin{array}{l}1.96 \\
3.07\end{array}$ & $\begin{array}{l}3.45 \\
4.48\end{array}$ & $\begin{array}{l}1.8 \\
1.5\end{array}$ & 10.6 & 2.719 & 0.359 & 10.37 & 19.90 & 0.132 & 1.9 & 3.0 & 560 & 163.8 & 36 & $\begin{array}{l}\text { Harzburgite } \\
\text { Dunite }\end{array}$ & $\begin{array}{l}\text { IRM } \\
\text { UWA, IRM }\end{array}$ \\
\hline $1 \mathrm{R}-3,122$ & 4.08 & 2.75 & 0.0004 & 0.012 & 0.001 & & 4 & & & & & & & & & 103.8 & & & \\
\hline $2 \mathrm{R}-1,85$ & 20.43 & & & & & & & $3.5 \mathrm{E}-4$ & $1.7 \mathrm{E}-5$ & 0.29 & 41.50 & 0.05 & 143.1 & $3.8 \mathrm{E}-4$ & & & & Olivine gabbro & TAMU \\
\hline $2 \mathrm{R}-2,18$ & 21.14 & & 0.0553 & 1.45 & 3.07 & 2.1 & 10.6 & & & & & & & & & 9.7 & 9.7 & Harzburgite & UWA, IRM \\
\hline $2 \mathrm{R}-2,56$ & 21.52 & & 0.0769 & 2.02 & 12.99 & 6.4 & & 2.530 & 0.458 & 10.81 & 21.06 & 0.18 & 1.9 & 2.8 & & 26 & 58 & Dunite & TAMU \\
\hline $2 \mathrm{R}-2,107$ & 22.03 & 2.47 & 0.0599 & 1.57 & 7.58 & 4.8 & 13 & & & & & & & & & 1 & 59 & Dunite & JR \\
\hline $3 \mathrm{R}-1.90$ & 30.50 & 2.35 & 0.03262 & 0.86 & 1.55 & 1.8 & & 1.370 & 0.208 & 11.11 & 21.34 & 0.152 & 1.9 & 1.5 & 579 & 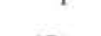 & (57 & Harzburgite & IRM \\
\hline $3 \mathrm{R}-2,24$ & 31.21 & & 0.0787 & 2.07 & 8.80 & 4.3 & & 2.360 & 0.345 & 8.71 & 17,42 & 0.15 & 2.0 & 2.6 & 4 & 171 & 46 & Dunite & TAMU \\
\hline $3 \mathrm{R}-2,55$ & 31.52 & 2.53 & 0.1154 & 3.03 & 10.34 & 3.4 & 10 & & & & & & & & & 151 & 37 & Dunite & $\mathrm{JR}$ \\
\hline $3 R-2.136$ & 32.33 & 2.60 & 0.13340 & 3.50 & & & & 4.650 & 0.712 & 9.20 & 19.10 & 0.153 & 2.1 & 5.1 & 579 & & & Dunite & IRM \\
\hline $3 R-3,14$ & 32.61 & 2.54 & 0.1254 & 3.29 & 4.67 & 1.4 & 9 & 4.290 & 0.442 & 8.93 & 19.44 & 0.10 & 2.2 & 4.7 & & -108 & 45 & Dunite & $\mathrm{JR}$ \\
\hline $4 \mathrm{R}-1,92$ & 40.42 & 2.37 & 0.04622 & 1.21 & 3.33 & 2.7 & 8.2 & 2.510 & 0.274 & 8.60 & 18.30 & 0.109 & 2.1 & 2.7 & & 304 & 34 & Dunite & $\begin{array}{l}\text { IRM } \\
\text { IRM }\end{array}$ \\
\hline $4 R-1,102$ & 40.52 & 2.53 & 0.0584 & 1.53 & 3.21 & 2.1 & 7 & & & & & & & & & -47 & 30 & $\begin{array}{l}\text { Dunite } \\
\text { Dunite }\end{array}$ & JR \\
\hline $4 \mathrm{R}-2,12$ & $\begin{array}{l}42.25 \\
4140\end{array}$ & & $\begin{array}{l}0.0660 \\
0.0501\end{array}$ & $\begin{array}{l}1.73 \\
1.31\end{array}$ & $\begin{array}{l}2.95 \\
3.53\end{array}$ & $\begin{array}{l}1.7 \\
2.7\end{array}$ & 10.3 & & & & & & & & & $\begin{array}{l}-54.2 \\
68\end{array}$ & $\begin{array}{l}22.5 \\
40\end{array}$ & $\begin{array}{l}\text { Dunite } \\
\text { Dunite }\end{array}$ & $\begin{array}{l}\text { UWA, IRM } \\
\text { TAMU }\end{array}$ \\
\hline $4 \mathrm{R}-2,58$ & 41.52 & & $\begin{array}{l}0.0501 \\
0.0519\end{array}$ & 1.36 & 3.93 & 2.9 & & 1.320 & 0.249 & 12.49 & 23.70 & 0.19 & 1.9 & 1.4 & & & & Dunite & TAMU \\
\hline $4 R-3,6$ & 42.47 & 2.87 & 0.0003 & 0.007 & 0.001 & 0.1 & & & & & & & & & & & & Gabbro (rodingite) & \\
\hline $5 \mathrm{R}-1,112$ & 51.02 & & 0.0610 & 1.60 & 3.04 & 1.9 & 11.7 & 2.745 & 0.528 & 16.20 & 27.95 & 0.19 & 1.7 & 3.0 & & 161.5 & 32.6 & Dunite & UWA, IRM \\
\hline $5 \mathrm{R}-1,145$ & 50.35 & 2.54 & 0.0675 & 1.77 & 4.35 & 2.5 & 9 & & & & & & & & & -143 & 45 & Dunite & $\mathrm{JR}$ \\
\hline $5 R-2,48$ & 50.88 & 2.60 & 0.05241 & 1.38 & 3.45 & 2.5 & 15.4 & 2.550 & 0.386 & 12.30 & 23.70 & 0.151 & 1.9 & 2.8 & 578 & 130 & 38 & Dunite & IRM \\
\hline $5 \mathrm{R}-2,115$ & 51.55 & 2.53 & 0.0763 & 2.00 & 4.78 & 2.4 & 7 & & & & & & & & & -74 & 27 & Dunite & $\mathrm{JR}$ \\
\hline $5 \mathrm{R}-2,132$ & 51.72 & & 0.0550 & 1.44 & 2.80 & 1.9 & & 2.020 & 0.256 & 11.47 & 24.43 & 0.13 & 2.1 & 2.2 & & 292 & 39 & Dunite & TAMU \\
\hline $5 \mathrm{R}-3,19$ & 52.09 & & 0.0494 & 1.30 & 2.80 & 2.2 & 11 & & & 11.41 & 24.45 & 0.15 & 2.1 & 2.2 & & -45.3 & 32.1 & Dunite & UWA, IRM \\
\hline $5 \mathrm{R}-3,35$ & 52.25 & & 0.0500 & 1.31 & & & & & & & & & & & & 70 & 43 & Dunite & TAMU \\
\hline $6 \mathrm{R}-1,131$ & 59.91 & & 0.0493 & 1.29 & 3.38 & 2.6 & & 1.360 & 0.216 & 11.21 & 22.72 & 0.16 & 2.0 & 1.5 & & 106 & 11 & Dunite & TAMU \\
\hline $6 \mathrm{R}-2,21$ & $60.3 i$ & & 0.0412 & 1.08 & 2.42 & 2.2 & & & 0.270 & 1.21 & 2,12 & 0.10 & 2.0 & & & 173 & 18 & Dunite & TAMU \\
\hline $6 \mathrm{R}-2,67$ & 60.77 & 2.54 & 0.03474 & 0.91 & 2.15 & 2.4 & & & & & & & & & & 178 & & Dunite & IRM \\
\hline $6 \mathrm{R}-2,85$ & 60.95 & & 0.0448 & 1.18 & 1.71 & 1.5 & 10.7 & 2.100 & 0.264 & 11.57 & 23.97 & 0.13 & 2.1 & 2.3 & & -7 & 15.6 & Dunite & UWA. IRM \\
\hline $6 \mathrm{R}-2,111$ & 61.21 & 2.58 & 0.0272 & 0.71 & 2.30 & 3.2 & 14 & 0.855 & 0.134 & 12.18 & 23.7 & 0.16 & 2.0 & 0.93 & & 50 & 11 & Dunite & $\mathrm{JR}$ \\
\hline $6 \mathrm{R}-3,17$ & 61.48 & & 0.0233 & 0.61 & 4.53 & 7.4 & 4.4 & 1.36 & 0.232 & 12.31 & 23.2 & 0.17 & 1.9 & 1.5 & & 126.1 & 4.5 & Dunite & UWA, IRM \\
\hline $6 \mathrm{R}-3,68$ & 61.99 & & 0.0250 & 0.66 & 1.11 & 1.7 & & & & & & & & & & 211 & 13 & Dunite & TAMU \\
\hline $6 \mathrm{R}-3,101$ & 62.32 & 2.59 & 0.0255 & 0.67 & 1.93 & 2.9 & 7 & & & & & & & & & -27 & 58 & Dunite & JR \\
\hline $6 \mathrm{R}-4,58$ & 63.00 & & 0.0308 & 0.81 & 2.10 & 2.6 & 12 & & & & & & & & & -154.5 & 35.5 & Dunite & UWA, IRM \\
\hline $6 \mathrm{R}-5,11$ & 63.86 & & 0.0156 & 0.41 & 2.27 & 5.5 & 10 & & & & & & & & & (1) & & Dunite & UWA, IRM \\
\hline $6 \mathrm{R}-5,40$ & 64.15 & & 0.0458 & 1.20 & 2.06 & 1.7 & & & & & & & & & & 59 & 38 & Dunite & TAMU \\
\hline $6 \mathrm{R}-5,66$ & 64.41 & 2.56 & 0.0465 & 1.22 & 5.25 & 4.3 & 7 & & & & & & & & & -115 & 17 & Dunite & $\mathrm{JR}$ \\
\hline $6 \mathrm{R}-5,74$ & 64.49 & 2.49 & 0.04718 & 1.24 & 1.88 & 1.5 & 12.7 & 1.610 & 0.186 & 8.79 & 18.69 & 0.116 & 2.1 & 1.8 & & 232 & 10 & Dunite & IRM \\
\hline $6 \mathrm{R}-5,95$ & 64.70 & 2.54 & 0.04577 & 1.20 & 2.22 & 1.8 & 16.4 & 1.070 & 0.100 & 0.13 & 10.09 & & 2.1 & 1.0 & 580 & 203 & 6 & Dunite & IRM \\
\hline $6 \mathrm{R}-6,27$ & 65.25 & & 0.0661 & 1.74 & 3.41 & 2.0 & 10.5 & & & & & & & & & 165.2 & 13.7 & Dunite & UWA, IRM \\
\hline $7 \mathrm{R}-1,81$ & 69.01 & & 0.0530 & 1.39 & 2.27 & 1.6 & 13.5 & & & & & & & & & 1.5 & 30.2 & Dunite & UWA, IRM \\
\hline $7 \mathrm{R}-1,113$ & 69.33 & & 0.0693 & 1.82 & 5.28 & 2.9 & 10.3 & 4.430 & 0.718 & 12.30 & 22.65 & 0.16 & 1.8 & 4.8 & & 4 & 28.1 & Dunite & UWA, IRM \\
\hline $7 \mathrm{R}-1,135$ & 69.55 & 2.55 & 0.05934 & $\begin{array}{l}1.82 \\
1.56\end{array}$ & $\begin{array}{l}3.20 \\
4.58\end{array}$ & 2.9 & 9.3 & $\begin{array}{l}4.450 \\
2.640\end{array}$ & 0.341 & 10.10 & 19.80 & 0.129 & 2.0 & $\begin{array}{l}4.8 \\
2.9\end{array}$ & 581 & 95 & $\begin{array}{c}28.1 \\
3\end{array}$ & Dunite & IRM \\
\hline $7 \mathrm{R}-2,102$ & 70.72 & 2.57 & 0.0464 & 1.22 & 2.79 & 2.3 & 12 & & & & & & & & & 94 & 30 & Dunite & $\mathrm{JR}$ \\
\hline $7 \mathrm{R}-3,28$ & 71.48 & & 0.0384 & 1.01 & 1.64 & 1.6 & 14.1 & & & & & & & & & 22.7 & 32.3 & Harzburgite & UWA, IRM \\
\hline $7 \mathrm{R}-3,39$ & 71.59 & & 0.0379 & 1.00 & 2.10 & 2.1 & & & & & & & & & & 106 & 34 & Harzburgite & TAMU \\
\hline $7 \mathrm{R}-3,60$ & 71.80 & 2.59 & 0.0356 & 0.94 & 2.12 & 2.3 & 10 & & & & & & & & & 20 & 35 & Dunite & $\mathrm{JR}$ \\
\hline $7 \mathrm{R}-3,86$ & 72.06 & 2.48 & 0.04039 & 1.06 & 1.94 & 1.8 & & 1.720 & 0.228 & 11.49 & 22.63 & 0.133 & 2.0 & 1.9 & & & & Dur & IRM \\
\hline $7 \mathrm{R}-3,125$ & 72.45 & & 0.061 & 1.6 & 3.19 & 2.0 & & & 0.2 & 9.26 & & 0 . & 2. & 2. & & 331 & -10 & Dunite & TAMU \\
\hline $7 \mathrm{R}-3,145$ & 72.65 & & 0. & 0.6 & 1.4 & 2.4 & 24 & 0.999 & 0.221 & 17.83 & 29.60 & 0.22 & 1.7 & 1.1 & & -153.8 & -13.2 & Dunite & UWA, IRM \\
\hline $7 \mathrm{R}-4,36$ & 73.06 & 2.66 & 0. & 0. & 1.04 & 3.1 & 11 & 0.624 & 0.116 & 15.82 & 26.40 & 0.19 & 1.7 & 0.68 & & 97 & 41 & Harzburgite & $\mathrm{JR}$ \\
\hline $7 \mathrm{R}-4,59$ & 73.29 & 2.62 & 0. & 0.3 & 1.12 & 3.4 & 15.8 & & & & & & & & & 93 & 31 & Harzburgite & IRM \\
\hline $8 \mathrm{R}-1,99$ & 78.89 & & 0.0457 & 1.20 & 2.98 & 2.5 & 22 & 1.820 & 0.209 & 9.62 & 24.05 & 0.11 & 2.5 & 2.0 & & -25.4 & 22.7 & Dunite & UWA, IRM \\
\hline $8 \mathrm{R}-1,113$ & 79.03 & 2.49 & 0.04530 & 1.19 & 2.49 & 2.1 & 22.5 & 1.580 & 0.231 & 11.46 & 22.05 & 0.146 & 1.9 & 1.7 & & 45 & -20 & Dunite & IRM \\
\hline $8 \mathrm{R}-1,120$ & 79.10 & & 0.0478 & 1.25 & 3.06 & 2.4 & & & & & & & & & & 233 & $\begin{array}{l}-17 \\
-17\end{array}$ & Dunite & TAMU \\
\hline $8 R-2,16$ & 79.55 & & 0.0738 & 1.94 & 3.50 & 1.8 & & & & & & & & & & 214 & -7 & Dunite & TAMU \\
\hline $8 \mathrm{R}-2,35$ & 79.74 & & 0.0591 & 1.55 & 2.41 & $\begin{array}{l}1.0 \\
1.6\end{array}$ & 23.3 & & & & & & & & & $\begin{array}{l}214 \\
-5.7\end{array}$ & -27.2 & Dunite & UWA, IRM \\
\hline $8 \mathrm{R}-2,57$ & 79.96 & 2.54 & 0.0592 & 1.55 & 3,72 & $\begin{array}{l}1.0 \\
2.4\end{array}$ & 7 & 2.650 & 0.363 & 11.04 & 21.97 & 0.14 & 2.0 & 2.9 & & 170 & 30 & Harzburgite & $\mathrm{JR}$ \\
\hline $8 \mathrm{R}-2,70$ & 80.09 & 2,48 & 0.03772 & 0.99 & 1.97 & 2.0 & 9.5 & 1.860 & 0.251 & 10.80 & 21.00 & 0.135 & 1.9 & 2.0 & 575 & 152 & 34 & Harzburgite & IRM \\
\hline $8 \mathrm{R}-2,90$ & 80.29 & & 0.0373 & 0.98 & 2.48 & 2.5 & & & & & & & & & & 60 & 18 & Harzburgite & TAMU \\
\hline $8 \mathrm{R}-2,100$ & 80.39 & & 0.0658 & 1.73 & 2.00 & 1.2 & 8.3 & 2.995 & 0.198 & 7.03 & 21.60 & 0.07 & 3.1 & 3.3 & & & & Harzburgite & UWA, IRM \\
\hline $8 \mathrm{R}-3,2$ & 80.82 & & 0.0470 & 1.23 & 3.53 & 2.9 & 22 & & & & & & & & & -140.8 & -16 & Dunite & UWA. IRM \\
\hline
\end{tabular}




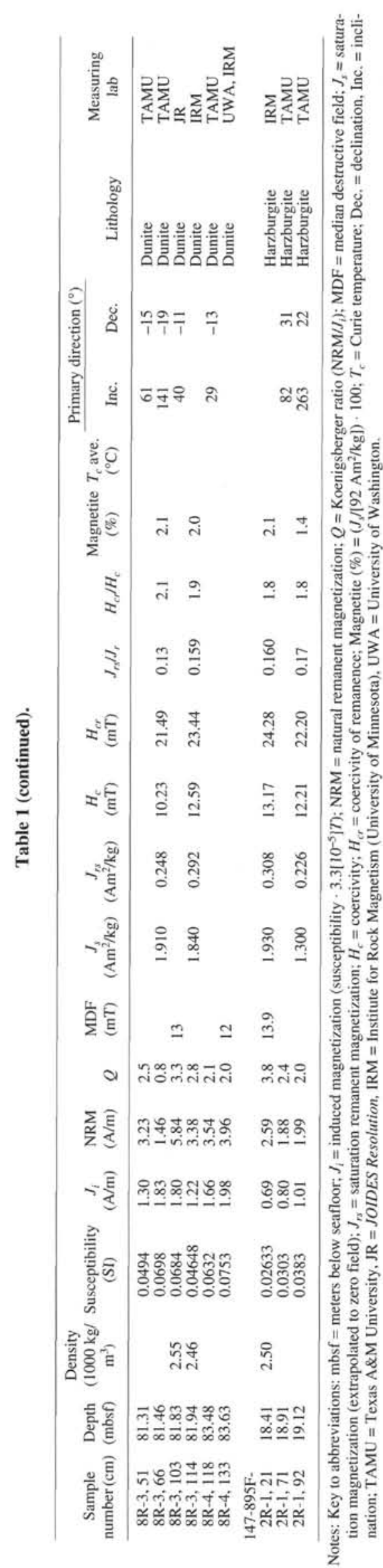

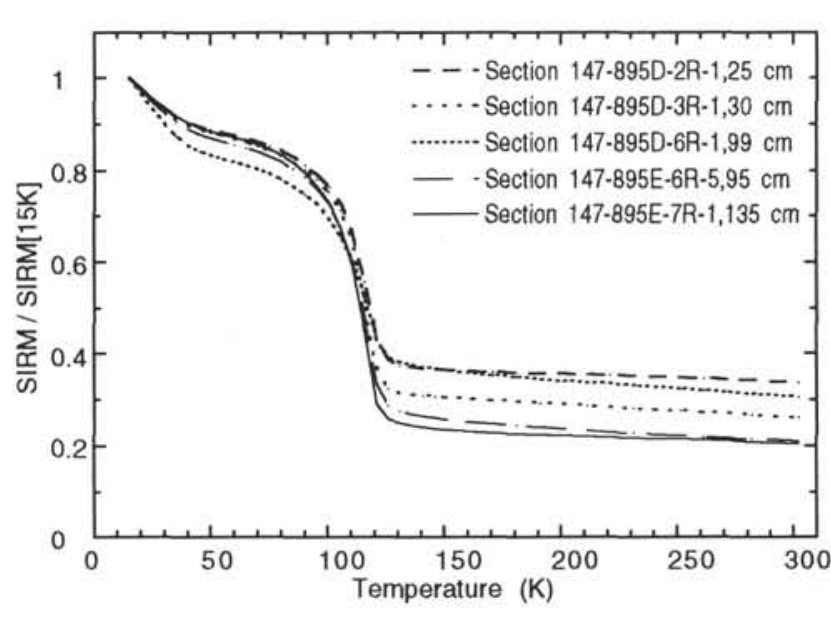

Figure 3. Saturation isothermal remanent magnetization given at $15 \mathrm{~K}$ (SIRM $[15 \mathrm{~K}])$ vs. temperature in a nominally zero field (less than a few millitesla) with the Verwey transition of magnetite evident at $\approx 118 \mathrm{~K}$.

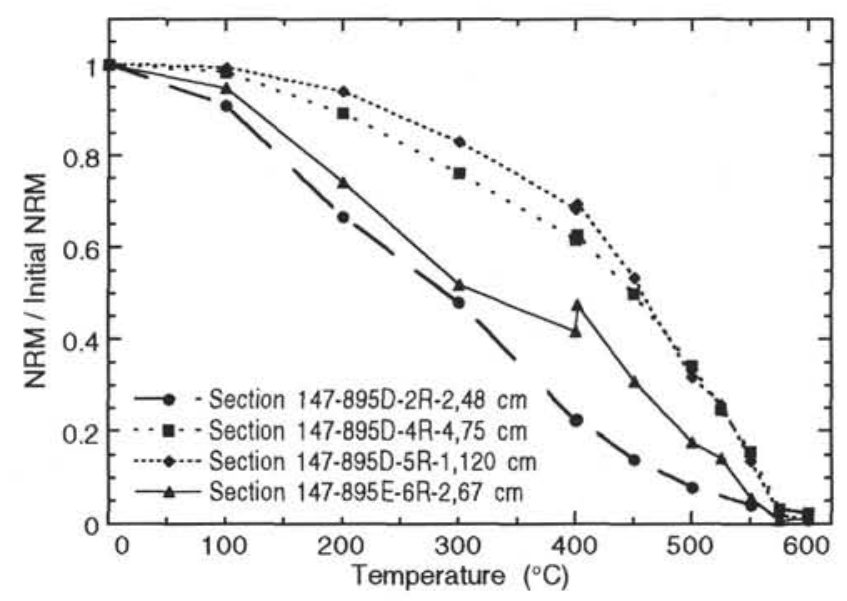

Figure 4. Thermal demagnetization of representative NRMs, normalized by their initial intensity. After the $400^{\circ} \mathrm{C}$ measurement, the samples were stored in zero field and remeasured, and then thermal demagnetization was continued.

als, dominantly magnetite, are secondary and are formed during the serpentinization process.

\section{Magnetization Intensity}

Assuming that magnetite is the only mineral that contributes to room-temperature hysteresis, the amount of magnetite can be calculated from the saturation magnetization extrapolated to zero field. The percentage of magnetite in individual samples is the of $J_{s}$ of the sample divided by $J_{s}$ of pure magnetite $\left(92 \mathrm{Am}^{2} / \mathrm{kg}\right)$ multiplied by 100 (Table 1). The median magnetite concentration in the dunites and harzburgites is $2.0 \%$ and $1.0 \%$, respectively.

Intensity values for the initial NRM are recorded in Table 1 . The median NRM intensity of the dunites and harzburgites is 3.2 and 1.2 $\mathrm{A} / \mathrm{m}$, respectively. A histogram of the NRM distribution is shown in Figure 6. We argue below that the samples have no significant drilling overprint; thus, the measured NRM should approximate the in situ magnetization. The observed magnetizations are similar in magnitude to those measured for oceanic basalts of seismic Layer 2a (e.g., Johnson and Pariso, 1993) and serpentinized peridotites from other 
A

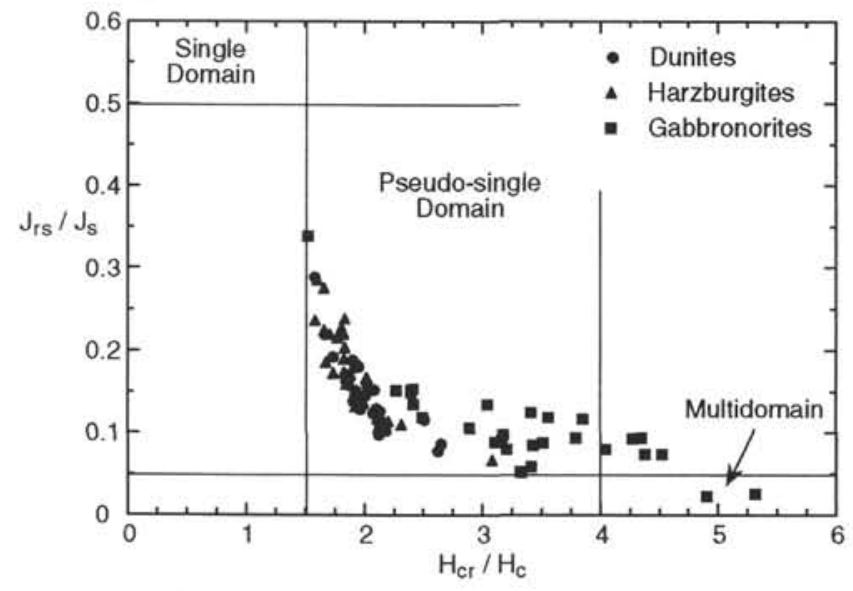

B

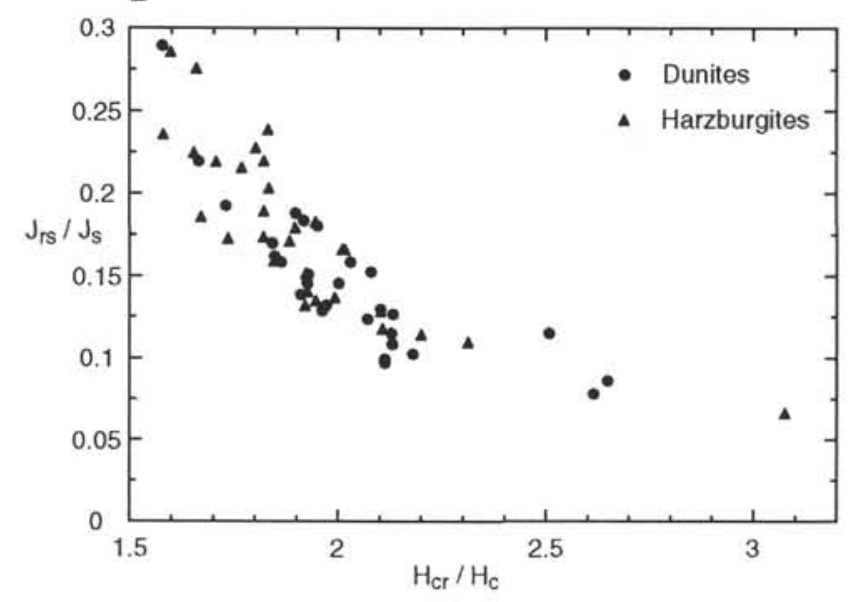

Figure 5. A. Day et al. (1977) diagram of the hysteresis properties of Leg 147 samples showing that the gabbronorites generally have a coarser bulk magnetic grain size than the peridotites. B. Expansion of a portion of the Day et al. diagram showing that on average the harzburgites have larger $J_{r s} / J_{s}$ and lower $H_{c r} J H_{c}$ ratios than the dunites.

ocean drilling studies (e.g., Dunlop and Prévot, 1982; Smith and Banerjee, 1985; Hamano et al., 1990).

The dunites and harzburgites have median low field magnetic susceptibilities of 0.053 and $0.023 \mathrm{SI}$, respectively. Values for individual samples are recorded in Table 1 and their distribution is shown in Figure 7. These values are similar to those previously reported for serpentinized peridotites recovered from the ocean floor (e.g., Dunlop and Prévot, 1982; Hamano et al., 1990). Temperature- and field-dependent susceptibility measurements show that the low field susceptibility is nearly entirely due to magnetite (Richter et al., this volume).

There is a general inverse relationship between the degree of serpentinization and density within peridotites because serpentine is less dense than its parent mineral, typically olivine and pyroxene (e.g., Toft et al., 1990). A plot of magnetic susceptibility vs. density for the harzburgites shows that susceptibility increases as density decreases (Fig. 8). This relationship suggests that the degree of serpentinization of the harzburgites may be an important factor contributing to the magnetic properties of oceanic peridotites. The highly serpentinized dunites fall within a relatively restricted density range. Thus, they show only a weak inverse correlation of susceptibility with density. Similar correlations were observed between the NRMs and densities for both the harzburgites and dunites. Highly serpentinized harzburgites have susceptibilities and densities comparable to those of the

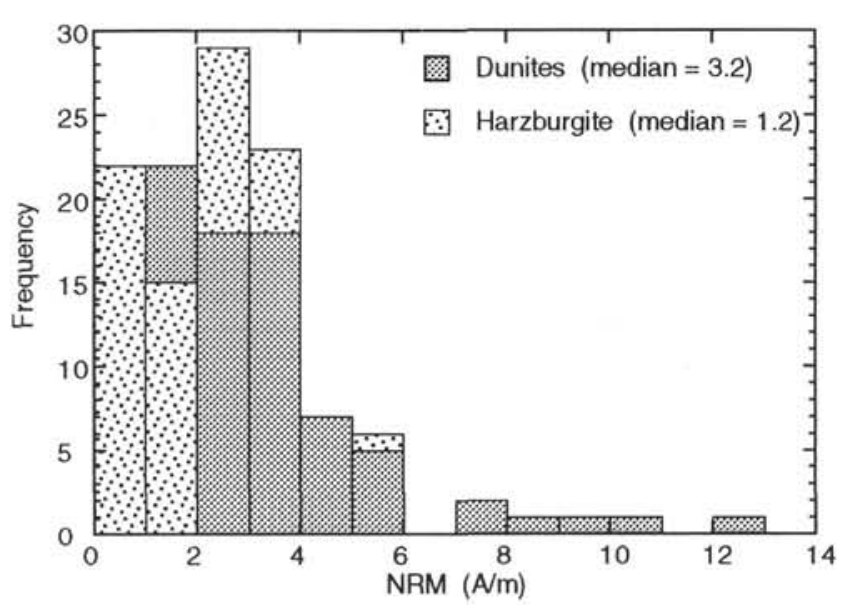

Figure 6. Histogram of the natural remanent magnetization of the dunites and harzburgites from Holes $895 \mathrm{D}$ and $895 \mathrm{E}$.

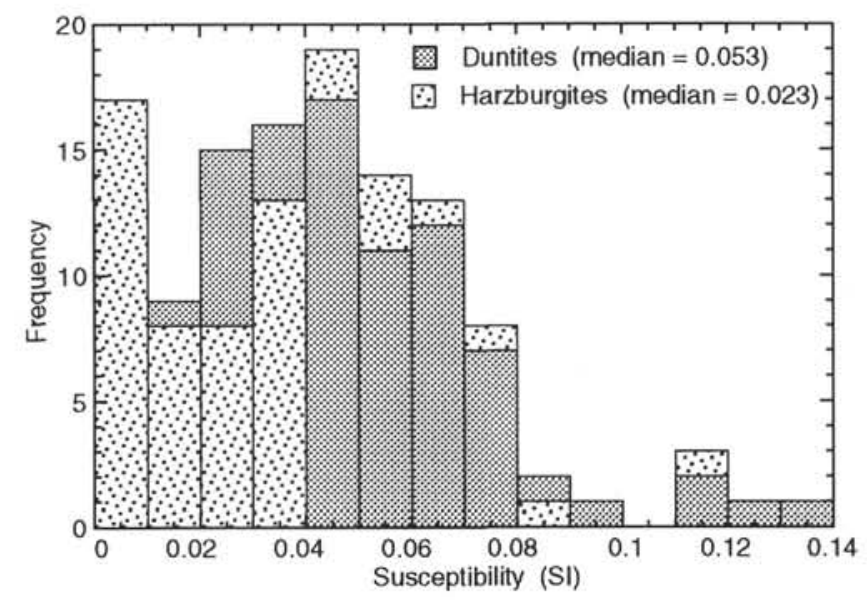

Figure 7. Histogram of the magnetic susceptibility of the dunites and harzburgites from Holes 895D and 895E.

dunites, suggesting that differences in magnetic properties between the harzburgites and dunites may, in large part, be due to differences in their average degree of serpentinization.

The median Koenigsberger ratio $(Q)$ for both the dunites and harzburgites is 2.4 , which means that the median NRM of the samples is 2.4 times larger than their induced magnetization $\left(J_{i}\right)$. The induced magnetization was calculated by multiplying the magnetic susceptibility times the present geomagnetic field at Site $895(3.3 \times$ $\left.10^{-5} \mathrm{~T}\right)$. The values of $J_{i}$ and $Q$ for individual samples are recorded in Table 1. Site $895 Q$ values are similar to those found for serpentinized oceanic peridotites by Dunlop and Prévot (1982) but nearly twice as high as values of serpentinized peridotites from ODP Hole 670A (Hamano et al., 1990).

The effect of temperature on the magnetic properties of these samples is an important factor since rocks residing at depth in the oceanic lithosphere are at elevated temperature. The NRM decreases with temperature (Fig. 4), whereas the magnetic susceptibility of PSDMD magnetite remains relatively constant with temperature up to near the Curie temperature (Richter et al., this volume). Therefore, the relative contribution of induced magnetization to magnetic anomalies increases with temperature. These peridotites contain a significant amount of serpentine, a hydrous mineral that is not stable at elevated temperatures $\left(>500^{\circ}-550^{\circ} \mathrm{C}\right)$. Therefore, as temperatures increase, serpentine begins to break down, causing changes in the magnetic mineralogy and/or the concentration of magnetic minerals. 


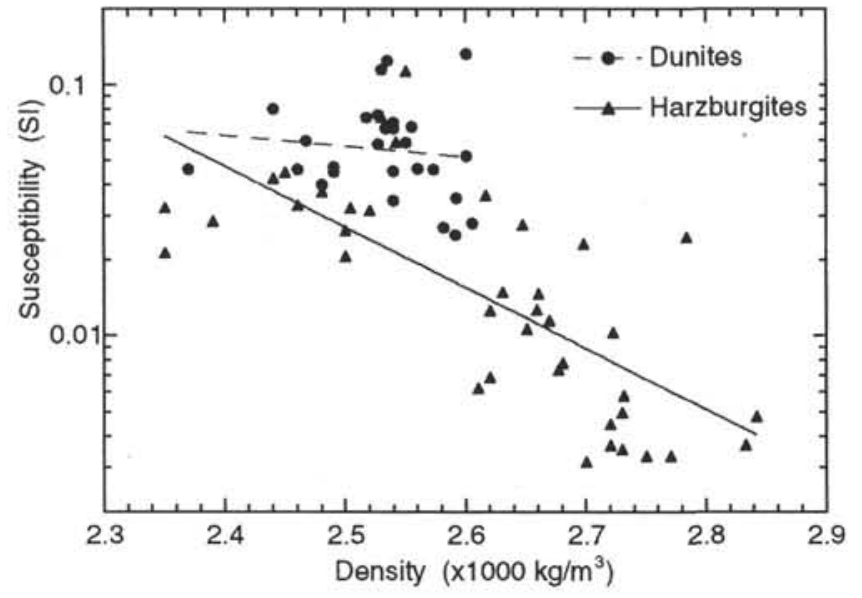

Figure 8 . Magnetic susceptibility is inversely related to density for the variably serpentinized harzburgites. Linear regressions through the data for the dunites (dashed line) and harzburgites (solid line) have correlation coefficients of 0.005 and 0.416 , respectively. The dunites are all highly serpentinized and therefore show only a weak correlation. At lower densities (i.e., higher degrees of serpentinization) the susceptibilities are similar for both the harzburgites and dunites.

\section{Paleomagnetism}

Petrologic and geochemical studies suggest that the serpentinization at Site 895 occurred at $350-450^{\circ} \mathrm{C}$ (Mével and Gillis; FrühGreen et al.; Mével and Stamoudi, all this volume), which is within the blocking temperature spectrum of magnetite. Therefore, the magnetization of the samples is part thermal remanent magnetization (TRM) and part chemical remanent magnetization (CRM). This growth in CRM will be along the ambient magnetic field at the time the grains grow through the critical volume, that is, above the superparamagnetic/single-domain threshold (e.g., Haigh, 1958). Thus, whether the magnetization is TRM or CRM, it will record the direction of the ambient geomagnetic field direction at the time the magnetization was acquired. There is currently no paleomagnetic technique to distinguish CRM from TRM if they have similar coercivity spectrums.

Examples of orthogonal vector diagrams (Zijderveld, 1967) for samples that have been either AF or thermally demagnetized are shown in Figure 9. Many of the samples display more than one magnetic component, but the primary component is easily recognizable. The least-squared fit of this component is recorded in Table 1 as the "primary component." Both AF and thermal techniques were equally successful in separating the individual components of magnetization. Therefore, most samples were $\mathrm{AF}$ demagnetized to eliminate any possibility of chemical alteration and to preserve them for future studies. The softest component often has a steeper inclination than the primary component. Because Site 895 rocks have always been located near the magnetic equator, it is unlikely that the soft component was produced by the geomagnetic field. It has been suggested (e.g., Johnson, 1978; Pariso and Johnson, 1993) that the drill string often induces a soft, near-vertical component of magnetization. We suggest that this generally soft, weak, high-inclination component of magnetization is drilling-induced.

The samples are fairly stable magnetically, with the hardest component often being the dominant one. The median destructive field (MDF) is a way to estimate the ease of AF demagnetization and is the AF field required to demagnetize half of the NRM. The MDF is 10.9 $\mathrm{mT}$ for the dunites and $13.1 \mathrm{mT}$ for the harzburgites (Fig. 10). The peridotites are much softer magnetically than the gabbronorites of Hole $894 \mathrm{G}$, which have an average MDF of $31 \mathrm{mT}$ (Pariso et al., this
147-895D-4R-1, $41 \mathrm{~cm}$

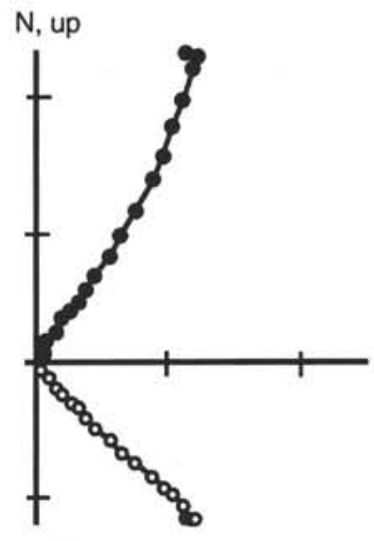

Tick interval: $200 \mathrm{~mA} / \mathrm{m}$

147-895D-4R-4, $75 \mathrm{~cm}$

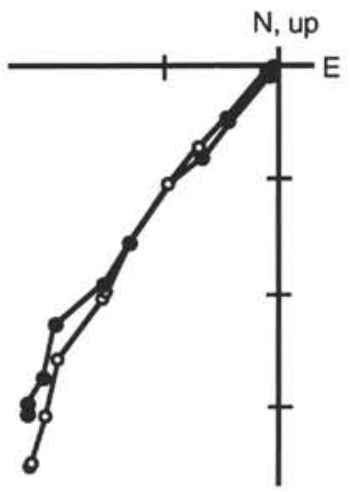

Tick interval: $200 \mathrm{~mA} / \mathrm{m}$
147-895D-6R-1, $99 \mathrm{~cm}$

N, up

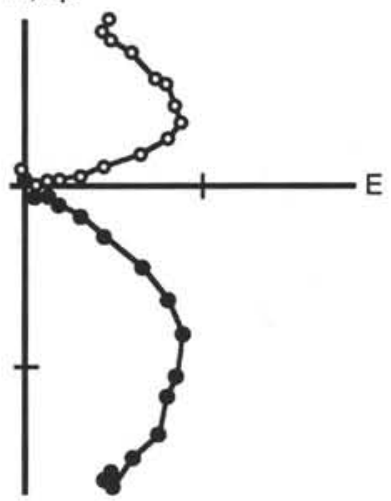

Tick interval: $1000 \mathrm{~mA} / \mathrm{m}$

147-895D-6R-2, $67 \mathrm{~cm}$

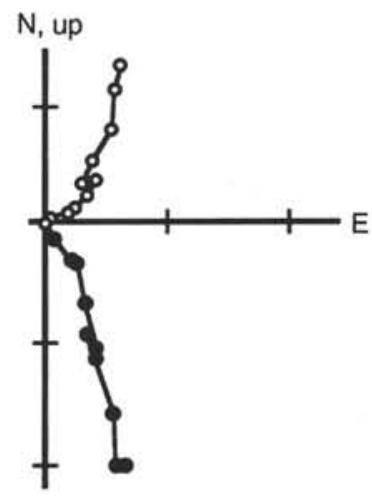

Tick interval: $2000 \mathrm{~mA} / \mathrm{m}$
Figure 9. Zijderveld plots from AF (upper diagrams) and thermal demagnetization (lower diagrams). Open circles denote the horizontal component (E, $\mathrm{N}$ ) and solid circles the east-west vs. the vertical (up-down) component. AF demagnetization steps were NRM, 1, 2, 4, 6, 8, 10, 13, 16, 20, 25, 30, 35, 40, $50,60,80$, and $100 \mathrm{mT}$. Thermal demagnetization steps were NRM, $100^{\circ}$, $200^{\circ}, 300^{\circ}, 400^{\circ}, 450^{\circ}, 500^{\circ}, 525^{\circ}, 550^{\circ}, 575^{\circ}$, and $600^{\circ} \mathrm{C}$.

volume), but are harder than the serpentinized peridotites of other studies that measured MDFs of $<10 \mathrm{mT}$ (e.g., Dunlop and Prévot, 1982; Hamano et al., 1990). The samples have a wide range of unblocking temperatures (Fig. 4), which is typical of relatively coarsegrained magnetite.

Because independent information on the horizontal orientation of the core does not exist, determination of the natural declination of the magnetization is not possible. Assuming that specimens originally had the same declination, it is possible to reorient individual segments of cores relative to one another using the magnetic declination. This was done successfully during the analysis of the fabric and structure orientations (MacLeod et al., Richter et al., both this volume).

\section{Viscous Remanent Magnetization}

One potential problem that often complicates the interpretation of paleomagnetic data is the acquisition of a viscous remanent magnetization (VRM). The tendency of Site 895 samples to acquire a shortterm ( $1 \mathrm{~s}$ to a few days) VRM was determined through room-temperature acquisition and decay experiments. Eight samples from Site 895 with an unaltered NRM were stored in a field-free space for 54 


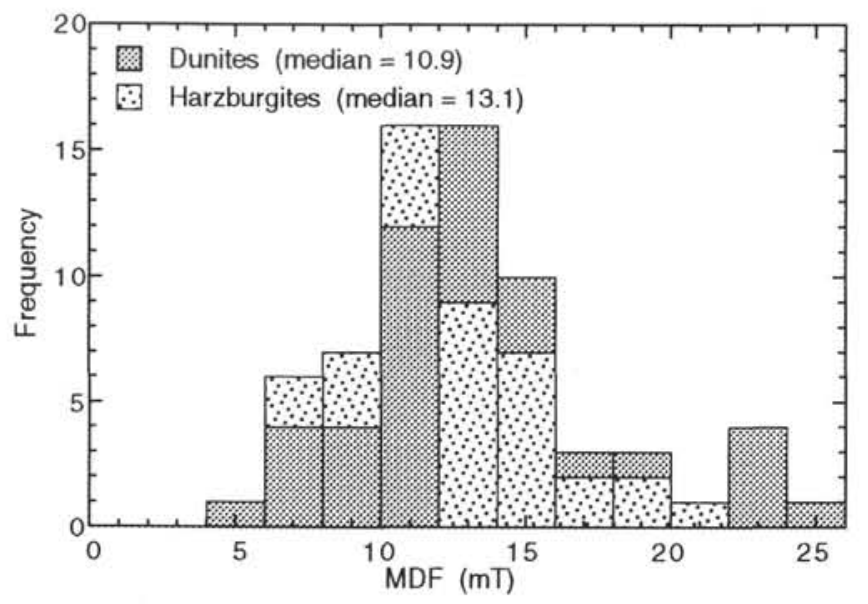

Figure 10. Histogram of the median destructive fields for the dunites and harzburgites from Holes $895 \mathrm{D}$ and $895 \mathrm{E}$.

days. The magnetization was measured periodically during this time. The change in the direction of magnetization was never more than a few degrees, which may largely be due to slight misorientations of the samples in the magnetometer. The intensity varied by less than $1 \%$. The one exception to this was Sample 147-895E-1R-2, 129-131 $\mathrm{cm}$, a highly magnetic dunite. This sample had a nearly $10 \%$ decrease in the NRM intensity, but there was negligible change in its direction. In the acquisition experiments, five samples with an unaltered NRM were placed for 131 days in a $0.1-\mathrm{mT}$ field ( 3 times the present-day geomagnetic field at Site 895). The magnetization of the samples was measured periodically by removing them from the field, making the measurement in zero field, and then replacing them, oriented as before, in the applied magnetic field. The field was oriented along the $\mathrm{X}$ axis (north) of the samples. NRM intensities changed by approximately $10 \%$ or less during the more than 4 months of this experiment. We conclude, from these experiments and from the steep magnetic inclinations observed in many samples, that if a room temperature VRM exists it does not dominate the magnetization, although it may be responsible for a secondary component of magnetization. These results are consistent with the viscous induced magnetization (VIM) study by Pozzi and Dubuisson (1992), who found that the VIM of Hess Deep serpentinites is negligible at room temperature but is more prevalent at elevated temperatures.

\section{DISCUSSION}

We have demonstrated that the Site 895 samples have a stable magnetization and that the inclination of the remanence should be the inclination of the geomagnetic field at the time the magnetization was acquired. Variation in the magnetic inclination within Holes 895D and $895 \mathrm{E}$ was examined by plotting the inclination vs. depth (Figs. $11,12)$. These samples are relatively young $(<1 \mathrm{Ma})$ and have always resided near the equator in a shallowly inclined magnetic field $\left(<20^{\circ}\right)$, even taking into account normal secular variations. Only during a magnetic reversal might the field be temporarily in a more inclined orientation. Serpentinization is a metamorphic process that often occurs over an extended time period. As metamorphism proceeds, magnetite grains gradually grow through their blocking volumes, with individual grains locking in their magnetization at different times. Within a single sample, magnetization is acquired over a long enough period of time to produce a time-averaged direction for the Earth's magnetic field. Thus, polarity transitions and secular variations in the field direction would be averaged out.

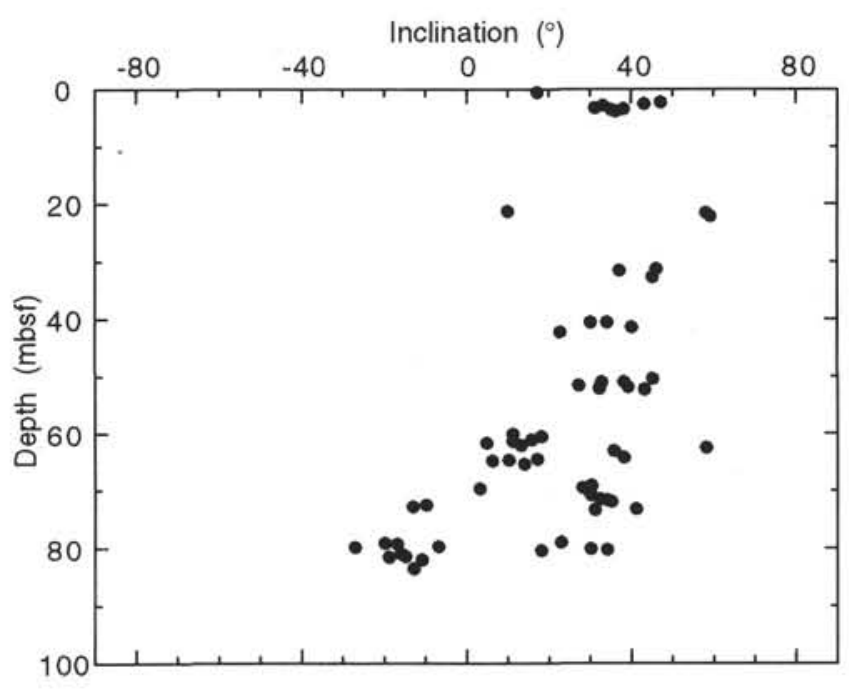

Figure 11. Stable paleomagnetic inclinations plotted as a function of depth (meters below seafloor) for Hole $895 \mathrm{E}$. The relatively consistent inclinations in the upper $55 \mathrm{~m}$ of the hole are more steeply dipping than the in situ geomagnetic field at this site. This is likely caused by tectonic rotation of a coherent block after magnetization. The decrease in inclination toward the bottom of the hole may be due to tectonic rotations or a deviation of the drill hole from vertical.

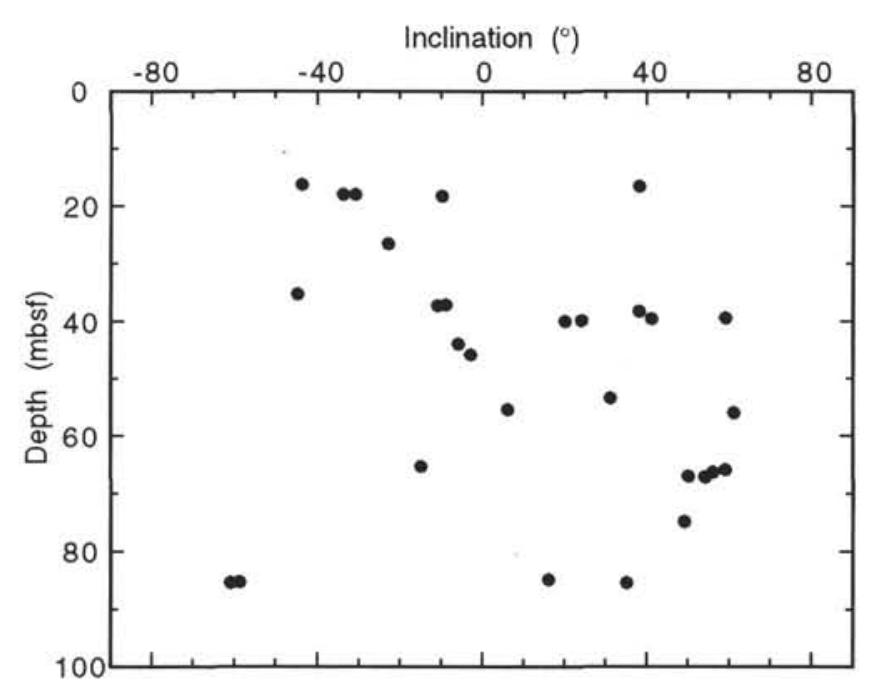

Figure 12. Stable paleomagnetic inclinations plotted as a function of depth (meters below seafloor) for Hole 895D. The lack of consistent inclination downhole suggests that the local region has experienced differential rotations of blocks of a few meters or less in size. These rotations may be the result of a very complicated tectonic history or, more likely, the hole was drilled in a landslide deposit, which caused the differential rotation of small blocks.

Figures 11 and 12 and Table 1 show that the stable magnetic inclination is often $>20^{\circ}$, which can be explained by sample rotation after acquisition of the magnetization. Figure 11 shows a general decrease in inclination with depth in Hole 895E. The average inclination in the upper portion of the hole is about $+30^{\circ}$ and it remains relatively constant throughout the upper $55 \mathrm{~m}$. Below this depth the average inclination begins to shallow and becomes negative at the bottom of the hole. This trend is possibly caused by tectonic rotations (e.g., on listric faults), by differential rotation of individual blocks, or 
by changes in the drill-hole dip with depth. The latter explanation requires a change in the dip within Hole $895 \mathrm{E}$ by approximately $40^{\circ}$, which is unlikely. No logging was performed at Site 895 so there is no independent information on the dip of the drill hole. The magnetic inclination in the upper portion of the hole is significantly greater than expected for an equatorial latitude. It is likely that Hole 895E underwent tectonic displacement that included at least $20^{\circ}$ of coherent rotation around a horizontal axis.

The magnetic inclinations of the samples from Hole 895D range from $+60^{\circ}$ to $-60^{\circ}$ with no downhole trends evident (Fig. 12). As argued above, the samples had an initially shallow inclination; thus, the widely scattered magnetic inclinations require differential rotation of relatively small blocks. It may be possible to explain the observed inclination variations as a complex sequence of tectonic rotations; however, an easier explanation is that this hole was drilled into a landslide, which caused the differential rotation of small individual blocks. It is possible that although the blocks have experienced differential rotations their relative positions may not have changed much. Thus, the initial stratigraphy within the hole may or may not have been seriously disrupted.

\section{CONCLUSIONS}

Nearly pure pseudo-single-domain magnetite is the dominant magnetic mineral in the peridotites of Site 895. The serpentinized dunites and harzburgites have median NRMs of 3.2 and $1.2 \mathrm{~A} / \mathrm{m}$, and median induced magnetization of 1.4 and 0.61 (SI units), respectively, which are similar to those of oceanic basalts, dikes, and gabbros. The dunites are more magnetic than the harzburgites, which may in part be a result of their higher degree of serpentinization. Assuming that serpentinized peridotites occur in the oceanic lithosphere, they are a potential contributor to marine magnetic anomalies observed at the ocean surface. The NRMs of the Site 895 samples are relatively stable and presumably a more important contributor to observed magnetic anomalies than variations in the induced magnetization of similar in situ rocks. However, serpentinized peridotites will have a more diffuse reversal boundary than the quickly cooled basalts of Layer $2 \mathrm{a}$ due to the length of time over which the magnetization was acquired. Serpentinized peridotites are even more likely a contributor to the longer-wavelength magnetic anomalies. The contribution of serpentinized peridotites to magnetic anomalies depends critically on the timing, length of time, degree, and depth extent of the serpentinization process and its resulting magnetization. A full understanding of these processes will require more studies of rocks from the uppermost mantle collected from representative environments in the ocean lithosphere, along with experimental studies on the process of magnetization during serpentinization.

\section{ACKNOWLEDGMENTS}

We wish to thank the Institute for Rock Magnetism (IRM) at the University of Minnesota where the majority of this work was conducted. The IRM is funded by the Keck Foundation, the National Science Foundation, and the University of Minnesota. We thank reviewers Paul Toft and Joseph Meert for helpful comments on the initial draft of this manuscript. This work was supported by USSSP grants to P.K. (147-20719b) and J.P. and a Deutsche Forschungsgemeinschaft grant to C.R. (R1576/1-2).

\section{REFERENCES}

Beske-Diehl, S.J., 1990. Magnetization during low-temperature oxidation of seafloor basalts: no large scale chemical remagnetization. J. Geophys. Res., 95:21413-21432.
Bina, M.M., and Henry, B., 1990. Magnetic properties, opaque mineralogy and magnetic anisotropies of serpentinized peridotites from ODP Hole 670A near the Mid-Atlantic Ridge. Phys. Earth Planet. Inter., 65:88103.

Bina, M.M., Henry, B., and Cannat, M., 1990. Magnetic anisotropy and some other magnetic properties of serpentinized peridotites from ODP Hole 670A. In Detrick, R., Honnorez, J., Bryan, W.B., Juteau, T., et al., Proc. ODP, Sci. Results, 106/109: College Station, TX (Ocean Drilling Program), 263-267.

Day, R., Fuller, M., and Schmidt, V.A., 1977. Hysteresis properties of titanomagnetites: grain-size and compositional dependence. Phys. Earth Planet. Inter., 13:260-267.

Dunlop, D.J., and Prévot, M., 1982. Magnetic properties and opaque mineralogy of drilled submarine intrusive rocks. Geophys. J. R. Astron. Soc., 69:763-802.

Francheteau, J., Armijo, R., Cheminée, J.L., Hekinian, R., Lonsdale, P.F., and Blum, N., 1990. 1 Ma East Pacific Rise oceanic crust and uppermost mantle exposed by rifting in Hess Deep (equatorial Pacific Ocean). Earth Planet. Sci. Lett., 101:281-295.

Frost, B.R., 1985. On the stability of sulfides, oxides, and native metals in serpentine. J. Petrol., 26:31-63.

, 1991. Magnetic petrology: factors that control the occurrence of magnetite in crustal rocks. In Lindsley, D.H. (Ed.), Oxide Minerals: Petrologic and Magnetic Significance. Mineral. Soc. Am., Rev. Mineral., 25:489-509.

Gillis, K., Mével, C., Allan, J., et al., 1993. Proc. ODP, Init. Repts., 147: College Station, TX (Ocean Drilling Program).

Haigh, G., 1958. The process of magnetization by chemical change. Phil. Mag., 3:267-286.

Hamano, Y., Bina, M.M., and Krammer, K., 1990. Paleomagnetism of the serpentinized peridotite from ODP Hole 670A. In Detrick, R., Honnorez, J., Bryan, W.B., Juteau, T., et al., Proc. ODP, Sci. Results, 106/109: College Station, TX (Ocean Drilling Program), 257-262.

Johnson, H.P., 1978. Paleomagnetism of igneous rock samples-DSDP Leg 45. In Melson, W.G., Rabinowitz, P.D., et al., Init. Repts. DSDP, 45: Washington (U.S. Govt. Printing Office), 387-396.

Johnson, H.P., and Pariso, J.E., 1993. Variations in oceanic crustal magnetization: systematic changes in the last 160 million years. J. Geophys. Res., 98:435-445.

Krammer, K., 1990. Rock magnetic properties and opaque mineralogy of selected samples from Hole 670A. In Detrick, R., Honnorez, J., Bryan, W.B., Juteau, T., et al., Proc. ODP, Sci. Results, 106/109: College Station, TX (Ocean Drilling Program), 269-273.

Lonsdale, P., 1988. Structural pattern of the Galapagos microplate and evolution of the Galapagos triple junction. J. Geophys. Res., 93:13551-13574.

Pariso, J.E., and Johnson, H.P., 1993. Do lower crustal rocks record reversals of the Earth's magnetic field? Magnetic petrology of gabbros from Ocean Drilling Program Hole 735B. J. Geophys. Res., 98:16013-16032.

Pozzi, J.P., and Dubuisson, G., 1992. High temperature viscous magnetization of oceanic deep crustal- and mantle-rocks as a partial source for Magsat magnetic anomalies. Geophys. Res. Lett., 19:21-24.

Prévot, M., Lecaille, A., and Mankinen, E.A., 1981. Magnetic effects of maghemitization of oceanic crust. J. Geophys. Res., 86:4009-4020.

Smith, G.M., and Banerjee, S.K., 1985. Magnetic properties of plutonic rocks from the central North Atlantic Ocean. In Bougault, H., Cande, S.C., et al., Init. Repts. DSDP, 82: Washington (U.S. Govt. Printing Office), 377-383.

Toft, P.B., and Arkani-Hamed, J., 1992. Magnetization of the Pacific Ocean lithosphere deduced from MAGSAT data. J. Geophys. Res., 97:43874406.

- 1993. Induced magnetization of the oceanic lithosphere and ocean-continent magnetization contrast inferred from Magsat anomalies. J. Geophys. Res., 98:6267-6282.

Toft, P.B., Arkani-Hamed, J., and Haggerty, S.E., 1990. The effects of serpentinization on density and magnetic susceptibility: a petrophysical model. Phys. Earth Planet. Inter., 65:137-157.

Zijderveld, J.D.A., 1967. AC demagnetization of rocks: analysis of results. In Collinson, D.W., Creer, K.M., and Runcorn, S.K. (Eds.), Methods in Palaeomagnetism: New York (Elsevier), 254-286.

Date of initial receipt: 2 August 1994

Date of acceptance: 11 January 1995

Ms 147SR-026 